\title{
ACTIVITIES AND SUMMARY STATISTICS OF RADON-222 IN STREAM- AND GROUND- WATER SAMPLES, OWL CREEK BASIN, NORTH-CENTRAL WYOMING, SEPTEMBER 1991 THROUGH MARCH 1992
}

By Kathy Muller Ogle and Roger W. Lee

U.S. GEOLOGICAL SURVEY

Open-File Report 94-93

Prepared in cooperation with the

SHOSHONE TRIBE and the NORTHERN ARAPAHOE TRIBE

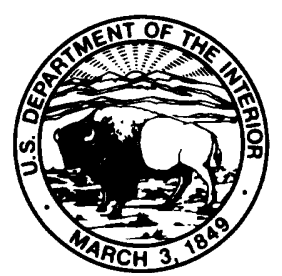

Cheyenne, Wyoming 


\section{U.S. DEPARTMENT OF THE INTERIOR \\ BRUCE BABBITT, Secretary}

U.S. GEOLOGICAL SURVEY

GORDON P. EATON, Director

For additional information write to:

District Chief

U.S. Geological Survey

Water Resources Division

2617 E. Lincolnway, Suite B

Cheyenne, Wyoming 82001-5662
Copies of this report can be purchased from:

U.S. Geological Survey

Earth Science Information Center

Open-File Reports Section

Box 25286, Denver Federal Center

Denver, Colorado 80225 


\section{CONTENTS}

Page

Abstract

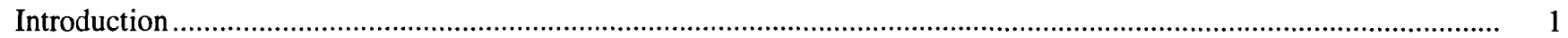

Purpose and scope

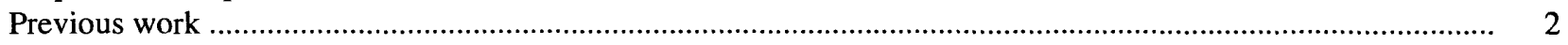

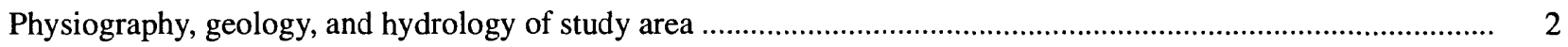

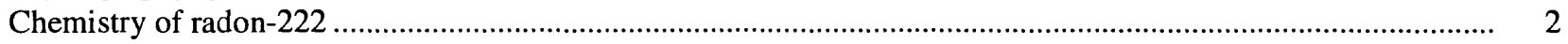

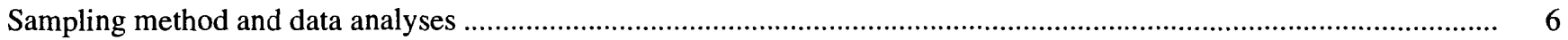

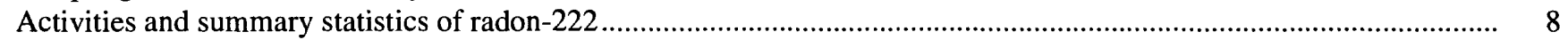

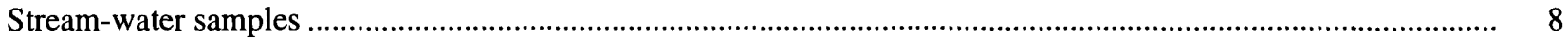

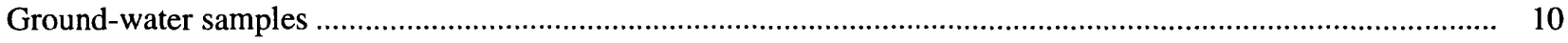

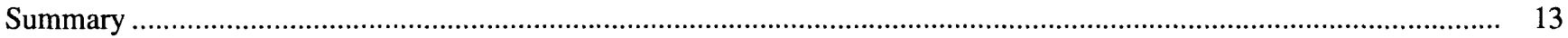

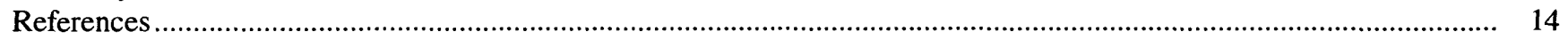

\section{FIGURES}

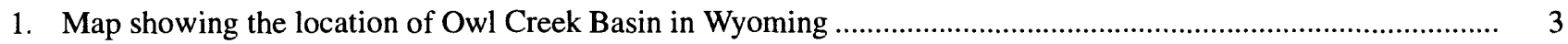

2. Map showing location of water-sampling sites in Owl Creek Basin, north-central Wyoming.............................. 4

3.-4. Graphs showing:

3. Radon-222 activities in stream-water samples, Owl Creek Basin, north-central Wyoming .............................

4. Arithmetic, geometric, and harmonic mean and median for radon-222 activity in water samples collected in Owl Creek Basin, north-central Wyoming ......................................................................... 10

5. Histograms showing the distribution of radon-222 activity in water samples collected in Owl Creek Basin, north-central Wyoming ........................................................................................................................... 11

6. Graph showing radon-222 activities in ground-water samples collected in Owl Creek Basin, northcentral Wyoming

\section{TABLES}

1. Radon-222 activities in stream-water samples, Owl Creek Basin, north-central Wyoming, November 1991 .........

2. Summary statistics of radon-222 activities in water samples, Owl Creek Basin, north-central Wyoming, September 1991 through March 1992

3. Radon-222 activities in ground-water samples, Owl Creek Basin, north-central Wyoming, September 1991 through March 1992 


\section{CONVERSION FACTORS}

\begin{tabular}{rll}
\hline Multiply & by & To Obtain \\
\hline inch & & millimeter \\
foot & 25.4 & meter \\
mile & 0.3048 & kilometer \\
square mile & 1.609 & square kilometer \\
acre & 2.590 & hectare \\
gallon per minute & 0.4047 & liter per minute \\
cubic foot per second & 3.785 & cubic meter per second \\
\hline
\end{tabular}

Sea Level: In this report, "sea level" refers to the National Geodetic Vertical Datum of 1929 (NGVD of 1929)--a geodetic datum derived from a general adjustment of the first-order level nets of both the United States and Canada, formerly called Sea Level Datum of 1929. 


\section{ACTIVITIES AND SUMMARY STATISTICS OF RADON-222 IN STREAM- AND GROUND- WATER SAMPLES, OWL CREEK BASIN, NORTH-CENTRAL WYOMING, SEPTEMBER 1991 THROUGH MARCH 1992}

By Kathy Muller Ogle and Roger W. Lee

\section{Abstract}

Radon-222 activity was measured for 27 water samples from streams and ground water in and near the Owl Creek Basin, a 510-square mile area in north-central Wyoming. Water samples were collected from September 1991 through March 1992. Summary statistics of the radon-222 activities were compiled. The radon-222 activities were measured as part of a comprehensive study of surface- and groundwater quality in the Owl Creek Basin undertaken cooperatively by the U.S. Geological Survey and the Shoshone Tribe and Northern Arapahoe Tribe.

Stream-water samples were collected at 16 sites along the main stem of Owl Creek and its tributaries. For the 16 stream-water samples, the arithmetic mean radon-222 activity was $20 \mathrm{pCi} / \mathrm{L}$ (picocuries per liter), geometric mean activity was $7 \mathrm{pCi} / \mathrm{L}$, harmonic mean activity was $2 \mathrm{pCi} / \mathrm{L}$, and median activity was $8 \mathrm{pCi} / \mathrm{L}$. The standard deviation of the arithmetic mean was $29 \mathrm{pCi} / \mathrm{L}$. The stream-water samples ranged from 0.4 to $97 \mathrm{pCi} / \mathrm{L}$. The histogram of stream samples are left-skewed compared to a normal distribution.

Ground-water samples were collected at 11 sites from an alluvial aquifer, bedrock aquifers, and a geothermal system. For the 11 ground-water samples, the arithmetic mean radon-222 activity was $486 \mathrm{pCi} / \mathrm{L}$, geometric mean activity was $280 \mathrm{pCi} / \mathrm{L}$, harmonic mean activity was $130 \mathrm{pCi} / \mathrm{L}$, and median activity was $373 \mathrm{pCi} / \mathrm{L}$. The standard deviation of the arithmetic mean was $500 \mathrm{pCi} / \mathrm{L}$. The radon-222 activities in the ground-water samples ranged from 25 to
$1,704 \mathrm{pCi} / \mathrm{L}$. The histogram of ground-water samples are left-skewed compared to a normal distribution.

\section{INTRODUCTION}

The radon-222 activities were measured as part of a comprehensive study of water quality in the Owl Creek Basin undertaken by the U. S. Geological Survey in cooperation with the Shoshone Tribe and Northern Arapahoe Tribe. Radon-222 is the radionuclide that represents the largest health risk of radionuclides in drinking water (Milvey and Cothern, 1990, p. 8). It is of increasing concern because of inhalation of radon-222 and the subsequent identified health risk from short-lived decay products. According to Milvey and Cothern (1990, p. 7) "Inhaled radon has been shown in several epidemiologic studies to lead to lung cancer." Hess and Beasley (1990, p. 193-202) identified radon-222 in water as sometimes contributing to the elevated radon-222 activities in air in homes. Radon-222 released from drinking water has been estimated to contribute about 7 percent of the radon-222 activity in air in homes (Cothern and others, 1986, p. 40).

\section{Purpose and Scope}

This report presents measurements and summary statistics of radon-222 activity in stream- and groundwater samples collected in and near the Owl Creek Basin from September 1991 through March 1992. Measurements of radon-222 activities were made at 16 selected sites along the major streams and at 
11 selected wells and springs in and near the Owl Creek Basin, Wyoming. Summary statistics of the radon-222 activities were compiled.

One water sample for radon-222 measurement was collected at each site. Selected stream, well, and spring sites are described with a site number, site name, date of sample collection, location, and altitude. A radon-222 activity in picocuries per liter and an analytical error are listed for each site. For ground-water samples, the geologic unit in which the well was completed or from which the spring issued is listed. The depth of the well and the water level are listed for wells, where available. Summary statistics and histograms were developed for radon-222 activities in stream-water samples and in ground-water samples.

\section{Previous Work}

Limited data are available on radon- 222 activities in water for Wyoming. Longtin (1990, p. 124) reported radon-222 activities for three samples of ground water used for public supply in Wyoming as part of the National Inorganic and Radionuclides Survey project conducted between 1984 and 1986 by the U. S. Environmental Protection Agency (USEPA). The activities of radon-222 in the three samples were 139,464 , and $680 \mathrm{pCi} / \mathrm{L}$. Catherine Shawki Ibrahim, and J.E. Johnson Tengerdy (Colorado State University, written commun., 1989) tested water samples from 103 community wells in Wyoming for radon-222 activity in 1988 and 1989 . Of the 327 samples collected by that study, the largest radon- 222 activity reported was $3,530 \mathrm{pCi} / \mathrm{L}$. While there have been two USEPA nationwide surveys (Michel, 1990, p. 90) and specific studies of radon-222 activities in small public water supplies, and private wells, there have been few studies of radon-222 activities in water from different sources in one basin.

\section{Physiography, Geology, and Hydrology of Study Area}

The Owl Creek Basin, in north-central

Wyoming, trends in an east-west direction and is west of Thermopolis (fig. 1). The drainage area of the basin is 510 square miles. The climate varies from semiarid in the lower parts of the basin, to sub-alpine in the vicinity of high peaks, paralleling the change in altitude from a low of 4,300 feet above sea level near the mouth of Owl Creek to a high of 12,518 feet at Washakie Needles (fig. 2). The topographic relief of the area is dominated by three features; the Owl Creek Mountains in the south, the Absaroka Range in the west, and the valley of Owl Creek and its major tributaries (fig. 2).

The geology of Owl Creek Basin is complex. Thirty geologic units were preliminarily mapped by Love and others (1979) on the Thermopolis quadrangle map ( 1 by 2 degrees), which includes most of the Owl Creek Basin. Igneous and sedimentary rocks are exposed in Owl Creek Basin (Love, 1939, p. 10). The oldest rocks in the area are igneous and metamorphic rocks of Precambrian age. From the Paleozoic era, rocks of the Cambrian, Ordovician, Devonian, Mississippian, Pennsylvanian, and Permian periods are found in Owl Creek Basin. Triassic, Jurassic, and Cretaceous rocks from the Mesozoic Era are present. From the Cenozoic era, both rocks of the Tertiary period and deposits of the Quaternary period are represented. The geologic structure in the basin is equally complex. Twenty-nine synclines and anticlines, 33 faults, and 5 thrust faults have been identified in the basin (Ogle, 1992, p. 5) at a 1:100,000 scale.

Owl Creek drains an elongated basin at the southern end of the Bighorn Basin. In general, Owl Creek flows west to east. The Owl Creek Basin was separated into three distinct drainage basin segments on the basis of stream-water quality: upper, middle, and lower segments (Ogle, 1992, p. 9). The streams in the middle and lower segments generally had concentrations of dissolved solids greater than $500 \mathrm{mg} / \mathrm{L}$ (milligrams per liter) (Ogle, 1992, p. 54). The groundwater resources in the basin were separated into two types of aquifer groups: an alluvial aquifer and bedrock aquifers (Ogle, 1992, p. 29). Within the bedrock aquifers, a geothermal system is associated with the crest of the Thermopolis Anticline (Hinckley and others, 1982, p. 12-20, 24-34). With the exception of two springs issuing from the Absaroka Volcanic Supergroup, selected ground-water samples from the alluvial and bedrock aquifers had concentrations of dissolved solids greater than $500 \mathrm{mg} / \mathrm{L}$ (Ogle, 1992, p. 54-55).

\section{Chemistry of Radon-222}

Radon-222 is a product of the radioactive decay of uranium-238 series (Wanty and Schoen, 1991, p. 183). Uranium decays through a series of elements to radium-226. Radium-226 decays directly to radon-222 (Hess and Beasley, 1990, p. 193). Other isotopes of radon (radon-219 and radon-220) occur 


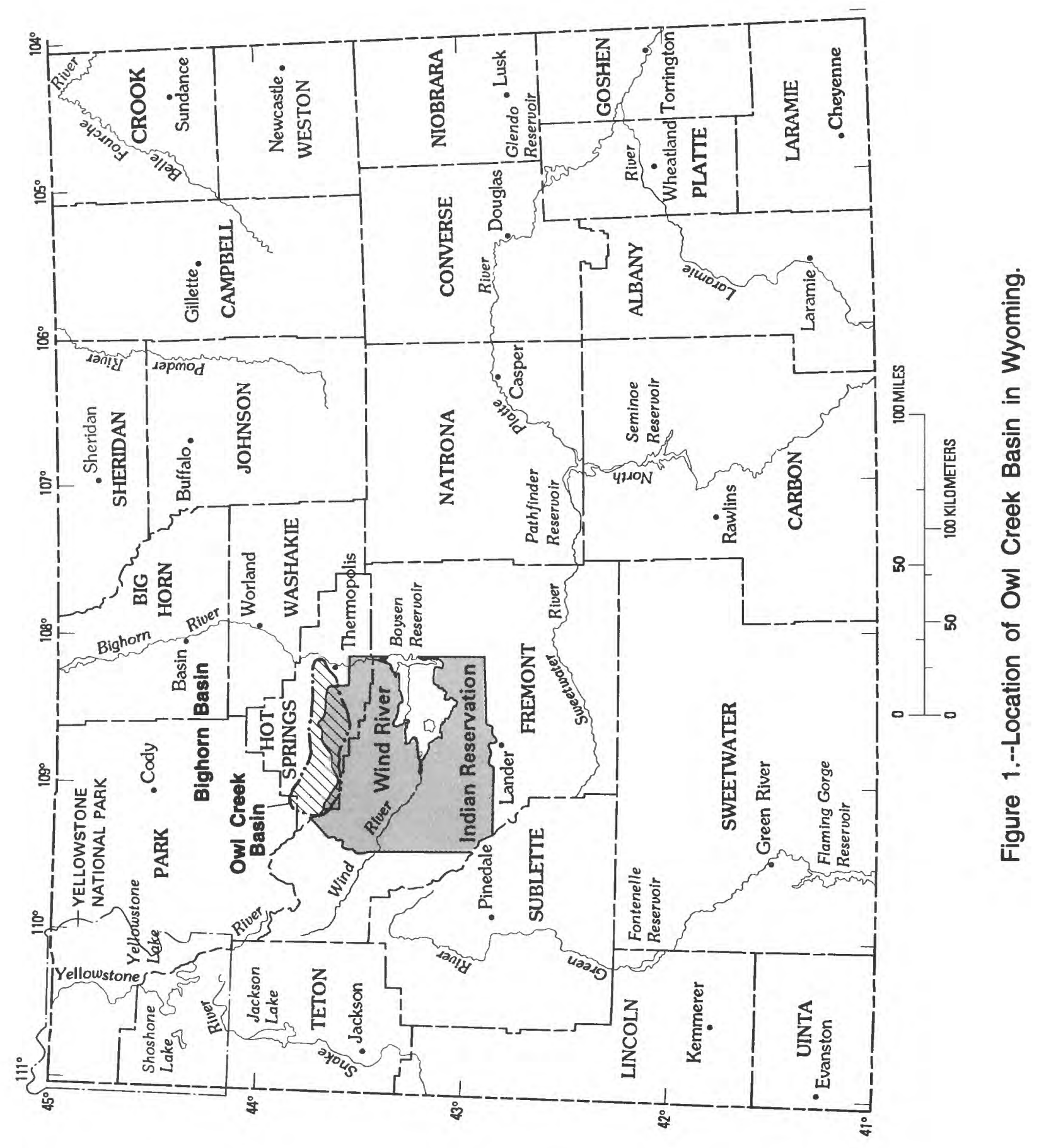




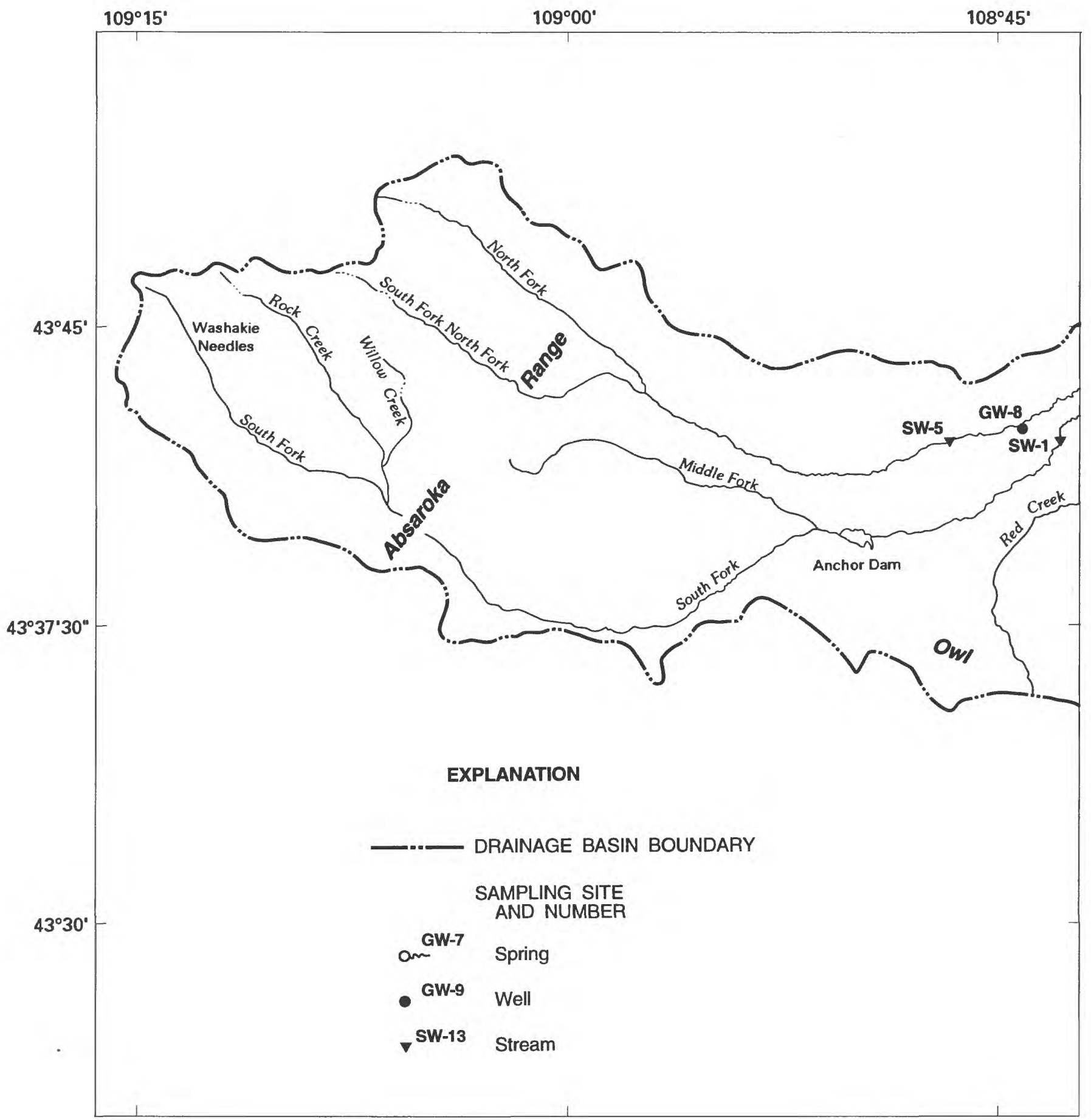

Figure 2. Location of water-sampling sites in Owl Creek Basin, north-central Wyoming. 


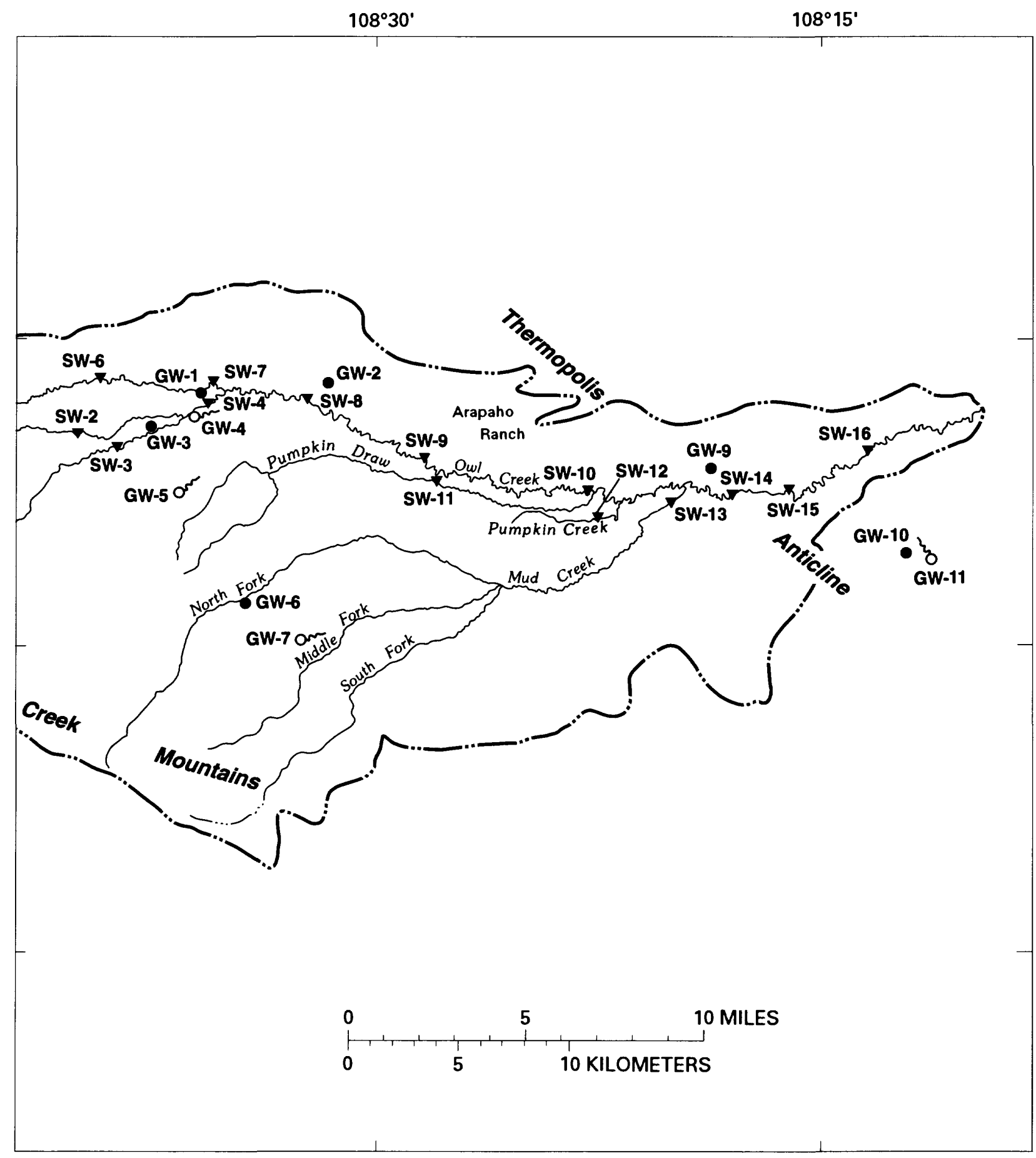


naturally but are of less concern for health risks because of their less frequent occurrence and short half-lives (Peake and Schumann, 1991, p. 163 and Kraemer, 1991, p. 316). Radon-222 is a naturally occurring, colorless, odorless, radioactive, noble gas (Henry and others, 1991, p. 65 and Lico and Rowe, 1991, p. 279). Radon-222 has a half-life of 3.82 days (Whittaker and others, 1987, p. 3) and emits a series of alpha and beta particles as it decays through the following series of short-lived isotopes: polonium-218, lead-214, bismuth-214, polonium-214, lead-210, bismuth-210, polonium-210 and finally to lead-206, a stable compound (Wanty and Schoen, 1991, p. 184186, Lico and Rowe, 1991, p. 279).

Radon-222 is soluble in water, and its solubility is related to water temperature (Wanty and Schoen, 1991 , p. 189). Radon-222 activity in ground water is related to the amount of radium-226 in the aquifer materials, the hydrology, and the structural geology; the amount of radium-226 in aquifer materials is the most important factor in most cases (Lee and Hollyday, 1991, p. 237). Kraemer (1991, p. 316-317) concluded that at salinities less than $95,000 \mathrm{mg} / \mathrm{L}$ of dissolved solids, the activity of radon-222 was likely related to the amount of radium-226 in the rock, and not to the concentration of radium-226 in the water.

Two pathways by which people are exposed to radon-222 present in water are ingestion from drinking the water and inhalation of radon-222 that has been released from the water (Mills, 1990, p. 29). Release of radon-222 from household water supplies as a result of activities, such as showering, washing clothes, or washing dishes, can increase the activity of radon-222 in indoor air (Lawrence and others, 1992, p. 177). The USEPA has proposed $300 \mathrm{pCi} / \mathrm{L}$ as a maximum contaminant level (MCL ${ }^{1}$ ) for radon-222 activity in public drinking-water supplies (U.S. Environmental

Protection Agency, 1991, p. 33050-33127).

\section{SAMPLING METHOD AND DATA ANALYSES}

Samples were collected and measured onsite from September 1991 through March 1992 using the methodology and calculations described by U.S.

\footnotetext{
${ }^{1} \mathrm{MCL}$ is an enforceable, health-based maximum level for contaminants in public drinking-water supplies.
}

Environmental Protection Agency (1980). Radon-222 gas was extracted from the water sample into calibrated lucas cells onsite.

Lucus cells (alpha-scintillation counting cells) were calibrated against radium-226 standards in water. The standards were capable of attaining 481 disintegrations per minute of radon- 222 at equilibrium. The standards were dissolved in about $200 \mathrm{ml}$ of distilled water and stored in glass graduate cylinders. The standards were sealed and allowed to reach equilibrium over a 3-week period prior to calibration of the lucas cells. Radon-222 gas was extracted from the standard container into the lucas cell using the onsite system. An average calibration factor for each cell was determined after scintillation counting for three 30-minute periods. Calibration factors ranged from 0.5 to 0.6 disintegrations per minute with an error of plus or minus 0.01 disintegrations per minute for each cell. Before sample collection, all lucas cells were purged and allowed to stabilize to background counts near zero scintillations. Baseline counts were obtained and recorded for the lucas cells using a Tennelec model AC/DC-DRC-MK10 dual radon counting system ${ }^{2}$.

Stream-sampling sites were selected in wellmixed sections of the streams between riffles and pools. The sample of stream water from the center of the wellmixed section was drawn through tubing into the evacuated cylinder with the intake tubing kept midway between the water surface and the streambed to avoid atmospheric and bed-sediment contamination. Before water samples were collected, the wells were pumped until $\mathrm{pH}$, temperature, and specific conductance stabilized. Samples were collected at the point of discharge for wells and springs to minimize the release of radon-222 to the atmosphere. The tubing connected to the evacuated cylinder was centered in the discharge to minimize any potential effect on radon- 222 activity in the water sample.

Radon-222 was extracted onsite from an approximately $200-\mathrm{ml}$ water sample collected in a vacuum-evacuated graduated cylinder. The time of the sampling was recorded, and radon-222 was extracted from the sample into a lucas cell. The fill time of the lucas cell and the volumetric quantity of the sample

\footnotetext{
${ }^{2}$ Use of the brand names in this report is for identification purposes only and does not constitute endorsement by the U.S. Geological Survey.
} 
were recorded. The lucas cells were stored at least 2 hours before counting to allow the radionuclides to achieve secular equilibrium.

All lucus cells were counted using the Tennelec counting system. The counts were performed within 12 hours of sample collection to minimize any loss of radon-222 due to lag time before counting. Each cell was allowed to stabilize in the counter before counting was started. Individual samples were counted a minimum of three times and a minimum of 20 minutes for each count. The count time was increased up to 120 minutes to assure accuracy of counts if a sample had a small radon-222 activity. The data were adjusted for volume of sample, time since sampling, and time since extraction to account for radon- 222 decay. The raw data in disintegrations per minute per liter were converted to picocuries per liter. A composite analytical error (background counts plus calibration error plus counting error) associated with the radon-222 activities was calculated for individual samples.

Individual radon-222 activities were grouped by stream-water samples and ground-water samples. Radon-222 activities in water samples for individual stream-water sampling sites are tabulated and plotted as bar graphs in site order from upstream to downstream. Radon-222 activities in water samples for individual ground-water sites were grouped by alluvial aquifer, bedrock aquifer, and geothermal system and plotted as bar graphs.

Basic summary statistics are calculated and distributions are presented in graphs for the radon-222 activities of stream-water samples and ground-water samples. No comparative tests were conducted because of the limited number of samples available. The following summary statistics were calculated or determined:

number of samples: the number of samples used in the data set to calculate the statistics and to plot the distribution.

low value of the range: the minimum value in the data set.

high value of the range: the maximum value in the data set. arithmetic mean: the sum of values of all measurements in the data set divided by the number of measurements made (modified from Chao, 1974, p. 97).

geometric mean: the product of the measurements taken to the root of the number of measurements (modified from Chow, 1964, p. 8-6).

harmonic mean: the reciprocal of the mean value of the reciprocals of individual measurements (modified from Chow, 1964, p. 8-6).

median: the value that is in the middle of the set of measurements arranged in order of magnitude (Chao, 1974, p. 100).

standard deviation: the square root of the arithmetic mean of the squared deviations from the arithmetic mean (Chao, 1974, p. 105).

The arithmetic, geometric, and harmonic mean and median are all measures of the central tendency of a data set. The arithmetic mean is calculated using the measurements of all samples and, if the variable is normally distributed, has the smallest sampling variance of measurements of central tendency (Yevjevich, 1972 p. 103). However, a disadvantage of the arithmetic mean is its sensitivity to extreme values, which is especially critical with small sample size (Bhattacharyya and Johnson, 1977, p. 29 and Yevjevich, 1972, p. 103). The geometric mean is sensitive to the number of measurements, distribution form, and skew (Landwehr, 1978, p. 471). The geometric mean is useful for many exponential relations in which the distribution of the data is asymmetrical (Yevjevich, 1972, p. 102-104). The geometric mean is smaller than the arithmetic mean if the distribution is log normal, but larger if the distribution is Pearson type 3, uniform, or Weibull (Landwehr, 1978, p. 471-472). The harmonic mean is sensitive to small values. For distributions where all values are positive and not all values are equal, the harmonic mean is smaller than the geometric mean and the geometric mean is smaller than the arithmetic mean (Kendall, 1987, p. 43-45). The median is not affected 
by a few very small or very large values, whereas the presence of such extreme measurements will have a significant effect on the arithmetic mean (Bhattacharyya and Johnson, 1977, p 29). By comparison of the differences in these measures of centrality, information can be obtained about the data set.

Histograms, showing the frequency of occurrence of radon-222 activities within a given range, are plotted for stream-water samples and for ground-water samples. The original data sets were log transformed, and the transformed data also are plotted as histograms.

\section{ACTIVITIES AND SUMMARY STATISTICS OF RADON-222}

Radon-222 activities were measured at 27 sites in or near the Owl Creek Basin (fig. 2): 16 stream-water sampling sites and 11 ground-water sampling sites. One water sample was collected at each site.

\section{Stream-Water Samples}

Radon-222 activities were determined for 16 selected stream-water sampling sites on the major tributaries and main stem of Owl Creek (table 1). Water samples were collected during low flow from November 13 through November 17, 1991. Radon-222 activities in the 16 stream-water samples ranged from 0.4 to $97 \mathrm{pCi} / \mathrm{L}$ (table 2 ). The radon-222 activities in stream-water samples ranged over three orders of magnitude (table 2). No measurements of radon-222 activity in stream-water samples were greater than the USEPA proposed MCL for drinking water of $300 \mathrm{pCi} / \mathrm{L}$ (fig. 3).

For the 16 stream-water samples, the arithmetic mean radon- 222 activity was $20 \mathrm{pCi} / \mathrm{L}$, the geometric mean activity was $7 \mathrm{pCi} / \mathrm{L}$, and the harmonic mean activity was $2 \mathrm{pCi} / \mathrm{L}$ (table 2 ). The standard deviation was $29 \mathrm{pCi} / \mathrm{L}$. The arithmetic mean is larger than the geometric mean, which in turn is larger than the harmonic mean (fig. 4). The median activity, $8 \mathrm{pCi} / \mathrm{L}$, is

Table 1. Radon-222 activities in stream-water samples, Owl Creek Basin, north-central Wyoming, November 1991

\begin{tabular}{clcccccc}
\hline $\begin{array}{c}\text { Sampling } \\
\text { site number } \\
\text { (fig. 2) }\end{array}$ & \multicolumn{1}{c}{ Site name } & $\begin{array}{c}\text { Sample } \\
\text { collection } \\
\text { date }\end{array}$ & $\begin{array}{c}\text { Latitude } \\
\text { (degrees, } \\
\text { minutes, } \\
\text { seconds) }\end{array}$ & $\begin{array}{c}\text { Longitude } \\
\text { (degrees, } \\
\text { minutes, } \\
\text { seconds) }\end{array}$ & $\begin{array}{c}\text { Altitude of } \\
\text { land surface } \\
\text { above sea } \\
\text { level } \\
\text { (feet) }\end{array}$ & $\begin{array}{c}\text { Radon-222 activity, in } \\
\text { picocuries per liter }\end{array}$ \\
\hline SW-1 & South Fork Owl Creek at bridge & $11-14-91$ & 434227 & 1084254 & 5,760 & 67 & $\begin{array}{c}\text { Analytical } \\
\text { error (+/-) }\end{array}$ \\
SW-2 & South Fork Owl Creek at Embar & $11-14-91$ & 434250 & 1084021 & 5,610 & 13 & 2 \\
SW-3 & Red Creek & $11-14-91$ & 434223 & 1083904 & 5,550 & .4 & 2.3 \\
SW-4 & South Fork Owl Creek at trailer & $11-14-91$ & 434326 & 1083551 & 5,375 & 9 & 1 \\
SW-5 & North Fork Owl Creek at bridge & $11-13-91$ & 434204 & 1084732 & 6,100 & 2.8 & 1.0 \\
SW-6 & North Fork Owl Creek in section 31 & $11-13-91$ & 434406 & 1083932 & 5,520 & 2.1 & .9 \\
SW-7 & North Fork Owl Creek at knob & $11-13-91$ & 434357 & 1083522 & 5,330 & 7 & 2 \\
SW-8 & Owl Creek at Arapahoe Ranch & $11-15-91$ & 434327 & 1083205 & 5,185 & 1.2 & 1.0 \\
SW-9 & Owl Creek at Middleton School & $11-15-91$ & 434207 & 1082817 & 5,000 & 6 & 1 \\
SW-10 & Owl Creek at steel bridge & $11-17-91$ & 434128 & 1082333 & 4,780 & 14 & 3 \\
SW-11 & Pumpkin Draw & $11-16-91$ & 434134 & 1082757 & 4,970 & 1.5 & 1.4 \\
SW-12 & Pumpkin Creek & $11-16-91$ & 434037 & 1082252 & 4,765 & 66 & 2 \\
SW-13 & Mud Creek & $11-16-91$ & 434104 & 1082005 & 4,650 & 97 & 3 \\
SW-14 & Owl Creek at Highway 120 & $11-17-91$ & 434106 & 1081804 & 4,575 & 14 & 1 \\
SW-15 & Owl Creek at sand points & $11-17-91$ & 434112 & 1081609 & 4,495 & 1.2 & 1.8 \\
SW-16 & Owl Creek at pumping station & $11-17-91$ & 434206 & 1081335 & 4,410 & 11 & 2 \\
\hline
\end{tabular}


Table 2. Summary statistics of radon-222 activities in water samples, Owl Creek Basin, north-central Wyoming, September 1991 through March 1992

[Activities, in picocuries per liter]

\begin{tabular}{|c|c|c|c|c|c|c|c|c|}
\hline \multirow{2}{*}{$\begin{array}{l}\text { Type of } \\
\text { sample }\end{array}$} & \multirow{2}{*}{$\begin{array}{c}\text { Number } \\
\text { of } \\
\text { samples }\end{array}$} & \multicolumn{2}{|c|}{ Range } & \multicolumn{3}{|c|}{ Mean } & \multirow[b]{2}{*}{ Median } & \multirow{2}{*}{$\begin{array}{l}\text { Standard } \\
\text { deviation }\end{array}$} \\
\hline & & Low & High & Arithmetic & Geometric & Harmonic & & \\
\hline Stream water & 16 & 0.4 & 97 & 20 & 7 & 2 & 8 & 29 \\
\hline Ground water & 11 & 25 & 1,704 & 486 & 280 & 130 & 373 & 500 \\
\hline
\end{tabular}
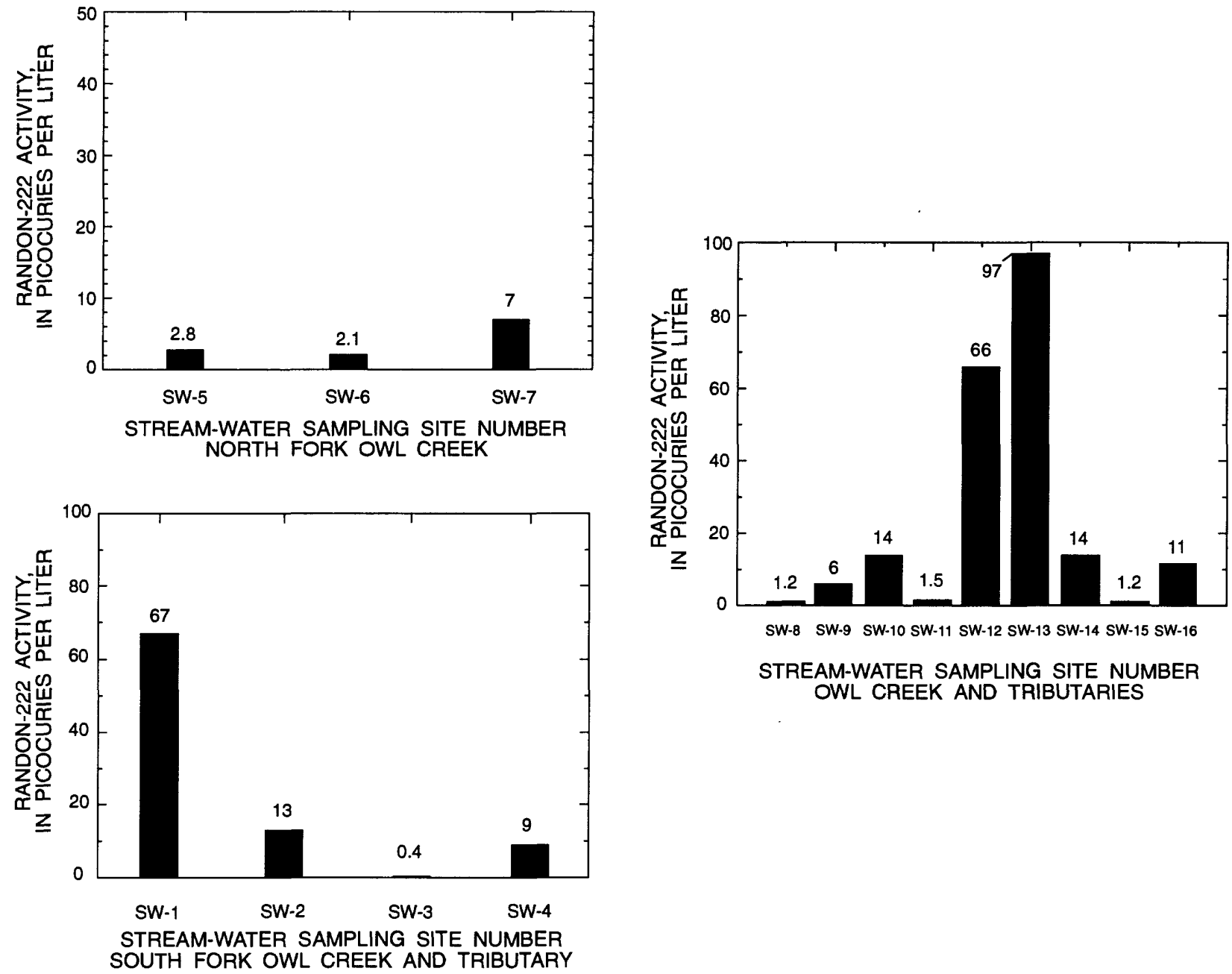

Figure 3. Radon-222 activities in stream-water samples, Owl Creek Basin, northcentral Wyoming. Proposed maximum contaminant level for radon-222 activity in drinking water is 300 picocuries per liter (U.S. Environmental Protection Agency, 1991). 
about the same value as the geometric mean. The histogram of the radon-222 activities in the stream-water samples is left-skewed (fig. 5a) compared to a normal distribution. After the data were log transformed (fig. 5b), the histogram more closely resembles a normal distribution.

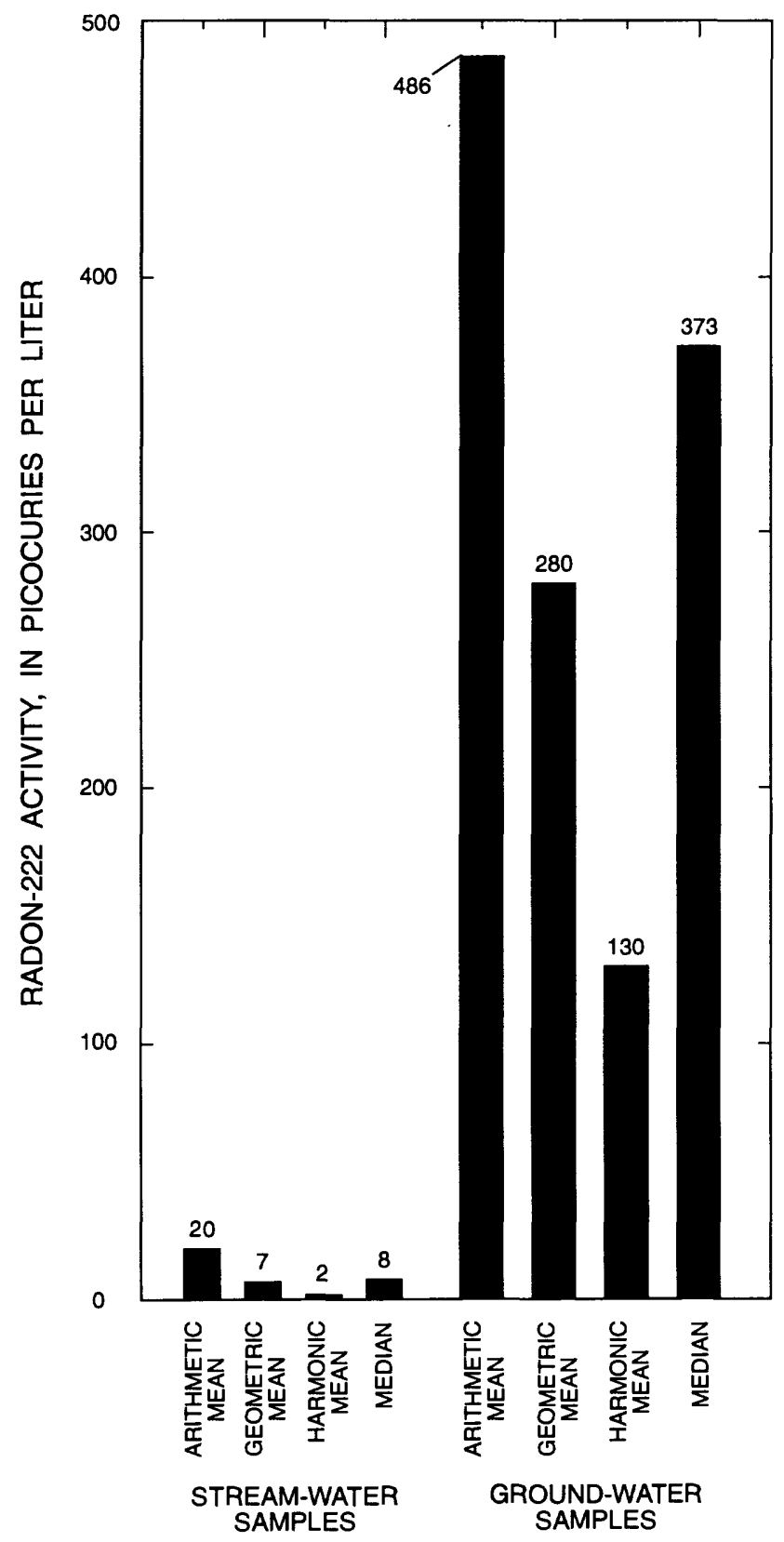

Figure 4. Arithmetic, geometric, and harmonic means and median for radon-222 activity in water samples collected in Owl Creek Basin, north-central Wyoming.

\section{Ground-Water Samples}

The water samples for radon-222 activity measurement were collected at nine selected groundwater sites in and two ground-water sites near the Owl Creek Basin from September 1991 through March 1992 (fig. 2). Four samples were from an alluvial aquifer, and seven were from water-yielding units in bedrock aquifers (table 3 ). Three samples were collected from wells (GW-9 and GW-10) and a spring (GW-11) that yield water from the Thermopolis Anticline geothermal system (Heasler and others, 1991) within the bedrock aquifers (fig. 6). Well GW-10 and spring GW-11 are located outside of the basin near the eastern boundary (fig. 2). Radon-222 activities in the 11 ground-water samples ranged from 25 to $1,704 \mathrm{pCi} / \mathrm{L}$ (table 2). The radon-222 activities in the ground-water samples varied by three orders of magnitude. Seven activities are greater than the USEPA proposed MCL of $300 \mathrm{pCi} / \mathrm{L}$ for radon-222 for drinking water, and four activities are less than the proposed MCL (fig. 6 and table 3).

For the 11 ground-water samples, the arithmetic mean radon- 222 activity was $486 \mathrm{pCi} / \mathrm{L}$, the geometric mean activity was $280 \mathrm{pCi} / \mathrm{L}$, the harmonic mean activity was $130 \mathrm{pCi} / \mathrm{L}$, and the median activity was $373 \mathrm{pCi} / \mathrm{L}$. The standard deviation was $500 \mathrm{pCi} / \mathrm{L}$. Milvey and Cothern (1990, p. 3) reported that "The average U.S. groundwater concentration of radon is in the range of 200 to $600 \mathrm{pCi} / \mathrm{L}$." Palsen $(1991, \mathrm{p} .199)$ summarized the radon-222 activities in samples of public ground-water supplies in the United States. He calculated the arithmetic mean to be $352.8 \mathrm{pCi} / \mathrm{L}$, and the geometric mean to be $86.6 \mathrm{pCi} / \mathrm{L}$. Lico and Rowe (1991, p. 287) reported a median activity of $480 \mathrm{pCi} / \mathrm{L}$ for 30 ground-water samples from the Carson Valley of Nevada. The arithmetic mean of the ground-water samples was greater than the geometric mean of the ground-water samples; the same relation was observed for the stream-water samples (fig. 4). The median is slightly closer to the geometric mean than the arithmetic mean.

The histograms for the ground-water data also are left skewed as compared to a normal distribution, (fig. 5c). The log transformed data (fig. 5d) more closely resemble a normal distribution. Log normal distribution has been noted in previous studies of radon-222 activities in ground water. Longtin (1990, p. 137) observed radon-222 activities from the National Inorganic and Radionuclides Survey project to be $\log$ normally distributed. Lico and Rowe (1991, 

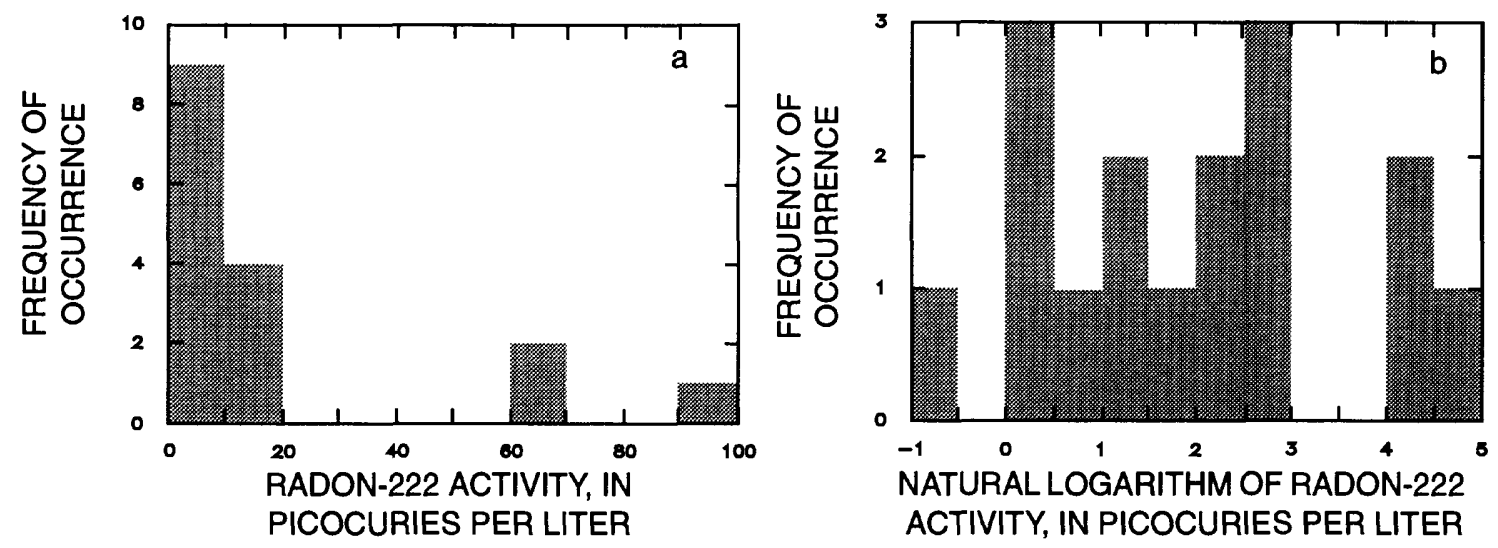

STREAM-WATER SAMPLES
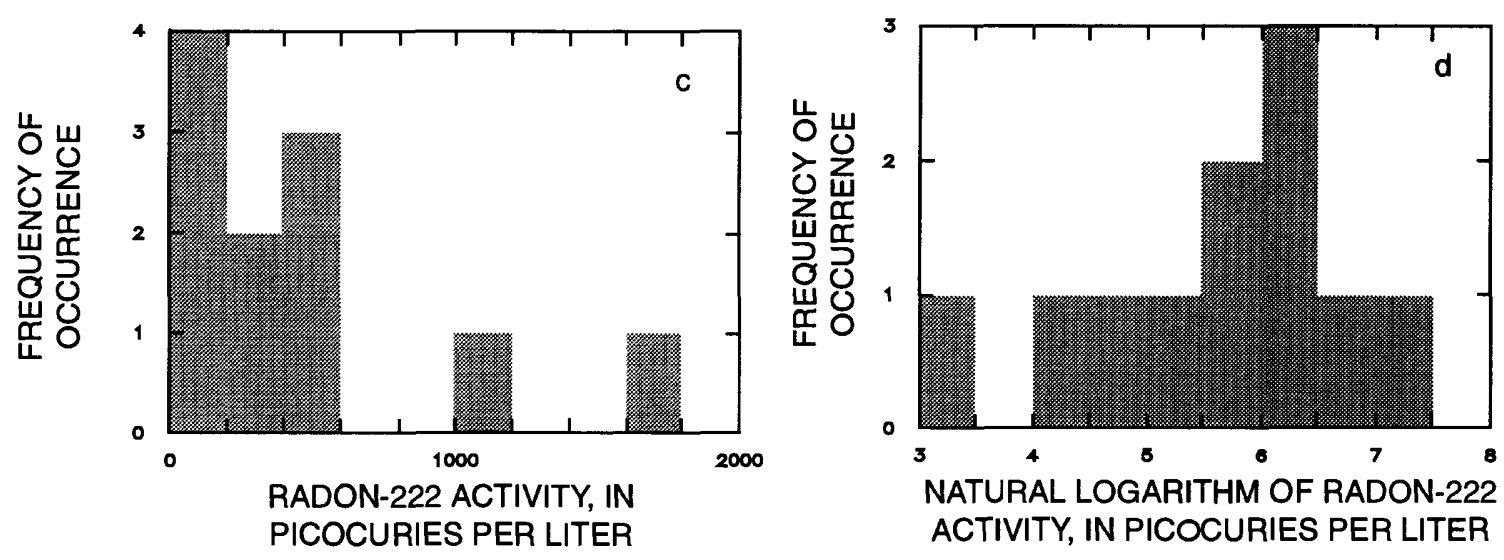

GROUND-WATER SAMPLES

Figure 5. Histograms showing the distribution of radon-222 activity in water samples collected in Owl Creek Basin, north-central Wyoming. 


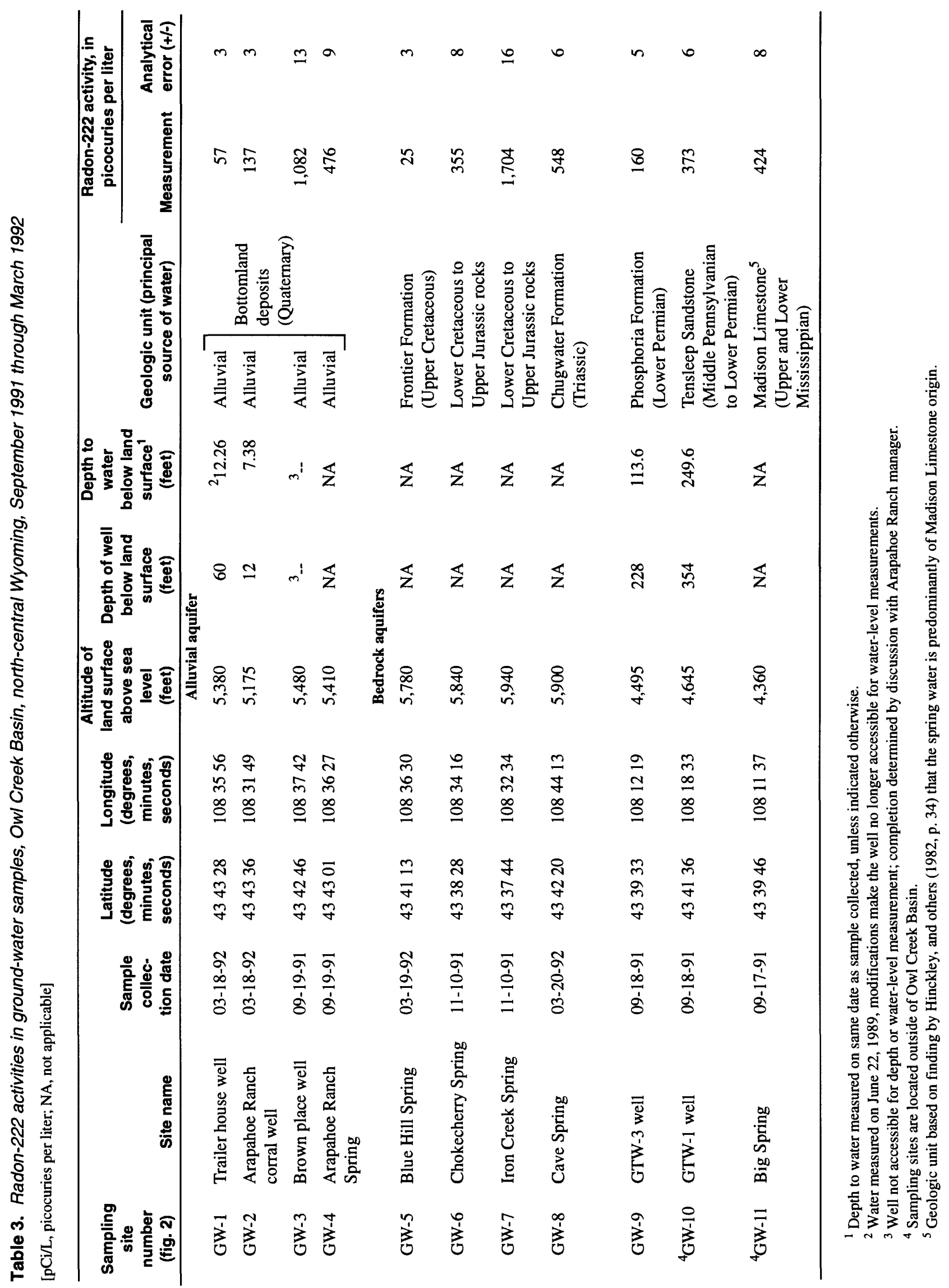




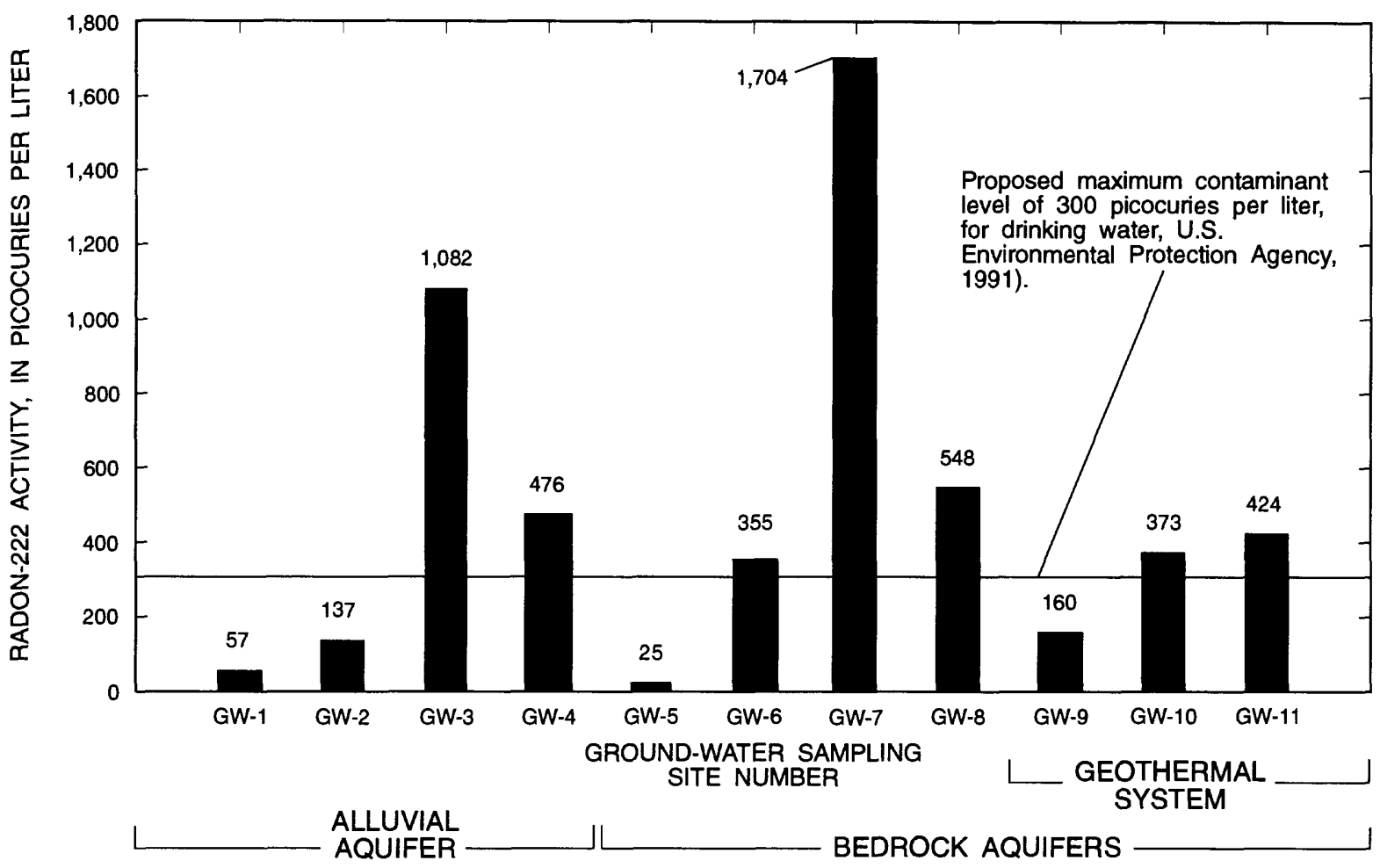

Figure 6. Radon-222 activities in ground-water samples collected in and near Owl Creek Basin, north-central Wyoming.

p. 283) also observed distribution of radon-222 activities in ground-water samples from Carson Valley, Nevada to be log normal. Measurements of radon-222 activity in 157 ground-water samples, which were collected throughout South Carolina, when plotted as log values, were normally distributed (King and others, 1982, p. 1175-1176).

\section{SUMMARY}

Radon-222 activity was measured in 27 water samples from streams and ground water in and near Owl Creek Basin, north-central Wyoming, from September 1991 through March 1992. One sample was collected at each stream- and ground-water sampling site.
Radon-222 activity was measured in water samples collected at 16 selected stream sites along the mainstem of Owl Creek and its tributaries.

Calculations of central tendency of the radon- 222 activities in the stream-water samples resulted in an arithmetic mean activity of $20 \mathrm{pCi} / \mathrm{L}$, geometric mean activity of $7 \mathrm{pCi} / \mathrm{L}$, harmonic mean activity of $2 \mathrm{pCi} / \mathrm{L}$, and median activity of $8 \mathrm{pCi} / \mathrm{L}$. The radon-222 activities in the stream-water samples ranged from 0.4 to $97 \mathrm{pCi} / \mathrm{L}$. The standard deviation of the arithmetic mean was $29 \mathrm{pCi} / \mathrm{L}$. The histogram of radon- 222 activities in the stream-water samples is left-skewed as compared to a normal distribution.

Radon-222 activity was measured in water samples collected at 11 ground-water sites; two sites, a well and a spring, are outside of the basin near the eastern boundary. Calculations of central tendency of the radon-222 activities in the ground-water samples resulted in an arithmetic mean activity of $486 \mathrm{pCi} / \mathrm{L}$, geometric mean activity of $280 \mathrm{pCi} / \mathrm{L}$, harmonic mean 
activity of $130 \mathrm{pCi} / \mathrm{L}$ and median activity of $373 \mathrm{pCi} / \mathrm{L}$. The radon-222 activities in the ground-water samples ranged from 25 to $1,704 \mathrm{pCi} / \mathrm{L}$. The standard deviation of the arithmetic mean was $500 \mathrm{pCi} / \mathrm{L}$. The histogram of radon-222 activities in the ground-water samples is left-skewed as compared to a normal distribution.

\section{REFERENCES}

Bhattacharyya, G. K. and Johnson, R. A., 1977, Statistical concepts and methods: New York, John Wiley and Sons, $639 \mathrm{p}$.

Chao, L. L., 1974, Statistics: An intuitive approach: Chicago, Science Research Associates, Inc., 344 p.

Chow, V. T., 1964, Handbook of applied hydrology: New York, McGraw-Hill Book Company, 1-1 through 2930.

Cothern, C. R., Lappenbusch, W. L., and Michel, Jacqueline, 1986, Drinking-water contribution to natural background radiation: Health Physics, v. 50, no. 1, p. 33-47.

Heasler, H. P., George, J. H., and Allen, M. B., 1991, Improved computational schemes for the numerical modeling of hydrothermal resources of Wyoming: U.S. Department of Energy Contract No DE-FG0788ID12738, 78 p.

Henry M. E., Kaeding, M. E., and Monteverde, Donald, 1991, Radon in soil gas and gamma-ray activity of rocks and soils at the Mulligan Quarry, Clinton, New Jersey, in Gundersen, L. C. S. and Wanty, R. B., eds., Field studies of radon in rocks, soils, and water: U. S. Geological Survey Bulletin 1971, p. 65-75.

Hess, C. T. and Beasley, S. M., 1990, Setting up a laboratory for radon in water measurements, in Cothern, C.R. and Rebers, R. A., eds., Radon, radium and uranium in drinking water: Chelsea, Mich., Lewis Publishers, Inc., p. 193-202.

Hinckley, B.S., Heasler, H. P., and King, J. K., 1982, The Thermopolis hydrothermal system with an analysis of Hot Springs State Park: The Geological Survey of Wyoming, preliminary report No. 20, $42 \mathrm{p}$.

Kendall, M.G., 1987, Distribution Theory, v. 1 of Kendall's advanced theory of statistics, (5th ed. by Alan Stuart and J.K. Ord): New York, Oxford University Press, $246 \mathrm{p}$.

King, P. T., Michel, Jacqueline, and Moore, W. S., 1982, Ground water geochemistry of ${ }^{228} \mathrm{Ra},{ }^{226} \mathrm{Ra}$, and ${ }^{222} \mathrm{Rn}$ : Geochimica et Cosmochimca Acta, v. 46, p. $1173-1182$.
Kraemer, T. F., 1991, Uranium, radium, and radon in deeply buried sediments of the U.S. Gulf Coast, in Gundersen, L. C. S. and Wanty, R. B., eds., Field studies of radon in rocks, soils, and water: U. S. Geological Survey Bulletin 1971, p. 313-318.

Landwehr, J. M., 1978, Some properties of the geometric mean and its use in water quality standards: Water Resources Research, v. 14, no. 3, p. 467-473.

Lawrence, E. P., Wanty, R. B., and Nyberg, Philip, 1992, Contribution of ${ }^{222} \mathrm{Rn}$ in domestic water supplies to ${ }^{222} \mathrm{Rn}$ in indoor air in Colorado homes: Health Physics Society, v. 62, no. 2, p. 171-177.

Lee, R.W., and Hollyday, E. F., 1991, Use of radon measurements in Carters Creek, Maury County, Tennessee, to determine location and magnitude of ground-water seepage, in Gundersen, L. C. S. and Wanty, R. B., eds., Field studies of radon in rocks, soils, and water: U.S. Geological Survey Bulletin 1971, p. 237-242.

Lico M. S., and Rowe T. G., 1991, Radon in ground water of Carson Valley, west-central Nevada: in Gundersen, L. C. S. and Wanty, R. B., eds., Field studies of radon in rocks, soils, and water: U. S. Geological Survey Bulletin 1971, p. 279-288.

Longtin, Jon, 1990, Occurrence of radionuclides in drinking water, a national study, in Cothern, C.R. and Rebers, R. A., eds., Radon, radium and uranium in drinking water: Chelsea, Mich., Lewis Publishers, Inc., p. $97-140$.

Love, J.D., 1939, Geology along the southern margin of the Absaroka Range, Wyoming: Geological Society of America Special Papers, no. 20, 134 p.

Love, J. D., Christiansen, A. C., Brown, T. M., and Earle, J. L., compilers, 1979, Preliminary geologic map of the Thermopolis $1 \times 2$ quadrangle, central Wyoming: U.S. Geological Survey Open-File Report 79-962, scale $1: 100,000$.

Michel, Jacqueline, 1990, Relationship of radium and radon with geological formations, in Cothern, C.R. and Rebers, R. A., eds., Radon, radium and uranium in drinking water: Chelsea, Mich., Lewis Publishers, Inc., p. 83-95.

Mills, W. A., 1990, Risk assessment and control management of radon in drinking water, in Cothern, C.R. and Rebers, R. A., eds., Radon, radium and uranium in drinking water: Chelsea, Mich., Lewis Publishers, Inc., p. 27-38. 
Milvey, Paul and Cothern, C. R., 1990, Scientific background for the development of regulations for radionuclides in drinking water, in Cothern, C.R. and Rebers, R.A., eds., Radon, radium and uranium in drinking water: Chelsea, Mich., Lewis Publishers, Inc., p. 1-16.

Ogle, K. M., 1992, Surface and ground-water quality in the Owl Creek basin, north-central Wyoming: U. S. Geological Survey Water-Resources Investigations Report 91-4108, 65 p.

Palsen, R. T., 1991, Radionuclides in ground water, rock and soil and indoor air of the northeastern United States and southeastern Canada--a literature review and summary of data, in Gundersen, L. C. S. and Wanty, R. B., eds., Field studies of radon in rocks, soils, and water: U. S. Geological Survey Bulletin 1971, p. 195-220.

Peake R. T. and Schumann, R. R., 1991, Regional radon characterizations, in Gundersen, L. C. S. and Wanty, R. B., eds., Field studies of radon in rocks, soils, and water: U. S. Geological Survey Bulletin 1971, p. 163-174.

U.S. Environmental Protection Agency, 1980, Prescribed procedures for measurement of radioactivity in drinking water, EPA/UOO/2-87/082, August 1980.

U.S. Environmental Protection Agency, 1991, National Primary Drinking Water Regulations; Radionuclides and Proposed Rule, Federal Register 56: 138, p. 33050-33127 (July 18, 1991).

Wanty, R. B. and Schoen, Robert, 1991, A review of the chemical processes affecting the mobility of radionuclides in natural waters, with applications, in Gundersen, L. C. S. and Wanty, R. B., eds., Field studies of radon in rocks, soils, and water: U. S. Geological Survey Bulletin 1971, p. 183-192

Whittaker, E.L., Akridge, J. D. and Giovino, J., 1987, Two test procedures for radon in drinking water interlaboratory collaborative study: EPA/600/2$87 / 082,45 \mathrm{p}$.

Yevjevich, Vujica, 1972, Probability and statistics in hydrology: Fort Collins, Colo., Water Resources Publications, $302 \mathrm{p}$. 